\title{
PENDAMPINGAN EKSTRAKURIKULER MERAJUT UNTUK MENGEMBANGKAN KREATIVITAS DAN KESIAPAN BERWIRAUSAHA SISWA MA MIFTAHUL ULUM KALIREJO PASURUAN
}

\author{
Ana Ahsana El-Sulukiyyah, Jihadti Renovani Puji Lestari, Mariyah \\ STKIP PGRI Pasuruan, Pasuruan, Indonesia \\ aahsana3@gmail.com
}

\begin{abstract}
Abstrak: Kegiatan pengabdian masyarakat ini dilaksanakan oleh tim KKN (Kuliah Kerja Nyata) STKIP (Sekolah Tinggi Keguruan dan Ilmu Pendidikan)-STIT (Sekolah Tinggi Ilmu Tarbiyah) PGRI (Persatuan Guru Republik Indonesia) Pasuruan didampingi oleh Dosen Pembina Lapangan di MA (Madrasah Aliyah) Miftahul Ulum Kalirejo. Kegiatan ini bertujuan untuk mengembangkan ekstrakurikuler merajut yang sebelumnya hanya menghasilkan topi rajut atau kupluk tanpa dipasarkan dan hanya disimpan di lemari penyimpanan. Metode yang digunakan terdiri dari tiga tahap yakni tahap persiapan, tahap pendampingan, dan praktek serta tahap pemasaran. Setelah melalui beberapa tahapan kegiatan tersebut terdapat peningkatan yang dicapai antara lain: (a) meningkatnya pengetahuan para siswi peserta workshop tentang teknik dasar merajut, (b) meningkatnya pengetahuan para siswi peserta pendampingan akan perbedaan teknik merajut yang biasa dipakai di Indonesia, (c) meningkatnya pengetahuan tentang macammacam jenis merajut, (d) meningkatnya keterampilan siswi peserta pendampingan dalam berkreasi membuat hasil rajutan yang bervariasi, (e) meningkatnya kemampuan para siswi peserta pendampingan dalam mebuat hasil rajutan yang rapi, padu padan warna yang indah dan layak jual, (f) meningkatnya pengetahuan siswi peserta pendampingan akan pemasaran yang tidak hanya melalui pasar offline tetapi juga dapat melalui pasar online, dan ( $\mathrm{g}$ ) terdapatnya akun media sosial bagi para siswi untuk memasarkan hasil rajutannya yakni akun instagram madrasah merajut. Dapat disimpulkan bahwa kegiatan pengabdian ini telah berhasil meningkatkan kreativitas dan kesiapan para siswinya untuk memulai kegiatan berwirausaha.
\end{abstract}

Kata Kunci: ekstrakurikuler; kreativitas; merajut; pendampingan; wirausaha

\begin{abstract}
This community service is carried out by KKN STKIP-STIT PGRI Pasuruan team supported by supervising lecturer at MA Miftahul Ulum Kalirejo. It aimed to develop an extracurricular program (knitting) that previously only produced knitted hats or skullcaps without being marketed and only stored in a storage cabinet. The method used in this program consist of three-step were the preparation step, the mentoring step, and the practice and marketing step. After going through several stages of the program, several improvements were achieved by the participants on: (a) knowledge of basic knitting techniques, (b) knowledge on the different knitting techniques commonly used in Indonesia, (c) knowledge of the different types of knitting, (d) skills in creating various knitting, (e) making neat, unified, beautiful color matching, and worth selling knitting, ( $f)$ knowledge in marketing strategy, either offline or online, and (g) social media (Instagram) account to market their knitwear, called madrasah merajut. To conclude, this community service has succeeded in increasing the creativity and readiness of the students to start entrepreneurship activities.
\end{abstract}

Keywords: extracurricular; creativity; knitting; coaching; entrepreneur

\section{Pendahuluan}

Madrasah Aliyah (MA) Miftahul Ulum Kalirejo Pasuruan merupakan madrasah yang berbasis pesantren yang terletak di Kabupaten Pasuruan Jawa Timur. Madrasah ini mempunyai kelompok belajar putra-putri yang disendirikan proses belajar mengajarnya. Kegiatan ekstrakurikuler juga dilaksanakan secara terpisah antara kelas putra dan putri. Pada kelas putra terdapat ekstrakurikuler pencak silat sebagai kegiatan yang ditonjolkan, sedangkan pada kelas 
putri terdapat ekstrakurikuler merajut. Kegiatan ekstrakurikuler merajut ini baru diadakan sebagai pengganti ekstrakurikuler menyulam yang dirasa sulit dan berat dilaksanakan oleh para siswi MA Miftahul Ulum Kalirejo. Kelemahan pada ekstrakurikuler ini adalah para siswa tidak terlebih dahulu dibekali dengan teknik dan teori merajut seperti teknik memegang jarum dan benang, jenis dan tipe merajut, dan jenis benang dan jarum. Para siswa secara langsung diminta merajut tanpa siswa mengetahui tekninya terlebih dahulu. Oleh karenanya perlu pelatihan merajut agar siswi mengetahui teknik secara benar.

Dalam kegiatan ekstrakurikuler merajut yang disebutkan diatas, para siswi hanya dilatih untuk membuat topi atau kupluk. Mereka langsung praktek tanpa adanya teori atau pengetahuan tentang pengenalan merajut bagi pemula. Sehingga walaupun kegiatan tersebut sudah berjalan hampir 4 bulan, mereka masih belum paham bagaimana teknik merajut yang baik walaupun mereka sudah bisa menghasilkan beberapa kup/uk (sejenis topi atau kopyah bagi pria yang berbahan rajut yang biasanya berwarna putih) yang kemudian hanya disimpan di lemari penyimpanan sebagai bukti bahwa ekstrakurikuler ini sudah menghasilkan suatu produk. Di sisi lain kegiatan ekstra kurikuler merupakan kegiatan yang mengasah kemampuan siswa agar menjadi sesuatu yang membanggakan (Halimah, 2014). Sehingga untuk mengoptimalkan kegiatan ekstra kurikuler merajut di MA Miftahul Ulum Kalirejo tersebut maka dilakukan pengabdian yakni pelatihan merajut sebagai upaya memberikan pengetahuan dasar merajut yang dilanjutkan dengan proses merajut yang dapat memberikan siswa pengalaman berwirausaha.

Pengabdian di MA Miftahul Ulum Kalirejo ini dilakukan oleh Mahasiswa KKN (Kuliah Kerja Nyata) dengan bimbingan dari dosen pembimbing lapangan (DPL) kemudian melakukan pendampingan untuk meningkatkan kreativitas dan kesiapan mereka dalam mengembangkan kegiatan ekstrakurikuler ini sebagai kegiatan yang lebih bernilai jual bagi para siswi tersebut. Dalam observasi awal ditemukan bahwa para siswi belum mengetahui teknik-teknik dasar merajut sehingga pengetahuan tentang teknik dasar merajut juga beberapa istilah dalam merajut perlu diberikan. Seperti dikatakan sebelumnya, kegiatan ini diperlukan pendampingan karena para siswi langsung menuju tahap praktek tanpa mengetahui pengetahuan akan teknikteknik merajut. Menurut Srikandi, Aisyah, \& Rosmiaty (2018) keterampilan dasar dan teknik dasar merajut perlu diberikan sebelum para siswi mempraktekkan langsung untuk merajut, hal ini akan berkaitan dengan hasil produksinya, meliputi kerapian dan keindahannya. Selain itu dengan mengetahui teknik dasar merajut, para siswi juga akan lebih kreatif mengembangkan hasil rajutannya. Hal ini juga dilakukan (Budi, Mhd, \& Niza, 2018) yang telah melakukan workshop merajut pada para ibu di Kampung Aur Medan dengan menggunakan beberapa metode. Metode tersebut diharapkan dapat menghasilkan simulasi yang lebih terarah dan efektif bagi para peserta workshop. Lebih jauh modul untuk kegiatan atau pelajaran merajut perlu diberikan sehingga para siswa yang belajar merajut baik itu untuk pelajaran intra seperti pada SMK Tekstil atau pelajaran ekstra seperti pada SMA atau MA pada umumnya mendapatkan bekal yang mumpuni terhadap kegiatan merajut yang mereka lakukan. Mereka tidak hanya asal merajut atau ketika memegang benang dan jarum mereka sudah merasa dirinya merajut, tetapi mereka dapat menguasai teknik dan dasar merajut sehingga hasil yang didapat juga 
memuaskan (Kartika, 2014).

Permasalahan yang kedua adalah hasil rajutan yang sudah ada tidak dipasarkan, hanya disimpan di dalam lemari. Oleh karena itu diperlukan pendampingan pemasaran hasil rajutan tersebut. Karena selain untuk mengembangkan kreativitas, kegiatan ini juga berguna untuk menyiapkan para siswi untuk mulai memasuki lapangan kerja dan mengenal pendidikan kewirausahaan. Hal ini sejalan dengan yang dilakukan oleh Sekolah Menengah Kejuruan El Hayat yang menjadikan kegiatan merajut sebagai kegiatan yang mengembangkan jiwa usaha (Siswanto, Mochtar, \& Prihantono, 2016). Selain itu saat ini, pemasaran hasiil kerajinan tangan semakin mudah dengan adanya teknologi, media sosial dan aplikasi jual beli online. Lebih jauh, (Habibullah, Roslina, Rinaldi, \& Zainnur, 2018) juga menyelenggarakan pendampingan merajut bagi ibu-ibu di Kelurahan Enggal, Bandar Lampung dan telah menghasilkan beberapa variasi produk rajutan yang kemudian dilanjutkan dengan pemberian merk rajutan dan juga dibantu dalam memasarkan hasil rajutan tersebut.

Masiah dan Adawiyah (2018) telah melakukan pengabdian masyarakat dengan memberdayakan para remaja desa untuk memproduksi produk handmade yang berdaya jual juga untuk mengurangi angka pernikahan dini. Apa yang dilakukan oleh pengabdi yang bertujuan untuk meningkatkan keterampilan dan kemampuan berwirausaha jelas sejalan dengan apa yang dilakukan oleh tim KKN STKIP-STIT PGRI Pasuruan. Dengan memberikan pendampingan praktek dan pemasaran diharapkan keterampilan merajut para siswi MA Miftahul Ulum Kalirejo Pasuruan dapat meningkat sehingga dapat memproduksi karya-karya rajutan yang bervariasi. Jadi selain menghasilkan produk awal yakni kupluk, para sisiwi juga bisa menghasilkan karya rajut lainnya seperti bros, gantungan kunci, bandana rajut dan dompet. Hal ini juga telah dilakukan oleh Widyastuti \& Sari (2017) yang juga memberikan pendampingan merajut untuk meningkatkan keterampilan para ibu Majlis Ta'lim. Para peserta pendampingan tersebut sudah dapat membuat berbagai variasi produk rajutan yaitu bros, dompet, tas, dan sepatu. Juga dikatakan bahwa antusiasme dan motivasi terhadap pendampingan merajut ini cukup tinggi, karena merajut merupakan kegiatan yang menarik.

Variasi hasil rajutan yang akan dipasarkan yang terlebih dahulu dibuat serapi dan sebagus mungkin dengan pendampingan praktek selama beberapa waktu, sehingga menghasilkan hasil yang rapi dan bernilai jual. Pemasaran dilakukan melalui sistem open order melalui akun media sosial yang juga didampingi cara pengelolaannya oleh mahasiswa KKN. Sehingga diharapkan ketika kegiatan pendampingan berakhir, para siswi sudah siap untuk berwirausaha dengan hasil rajutannya yang berdaya jual dan menghasilkan laba.

Melihat beberapa masalah yang terdapat pada kegiatan ekstrakurikuler merajut ini, maka tim pengabdi menyimpulkan untuk memberikan pendampingan merajut dengan memperkenalkan teknik-teknik dasar merajut dan pendampingannya, kemudian memberikan contoh variasi hasil rajutan yang dapat bernilai lebih untuk dipasarkan pada media online. 


\section{Metode}

Sasaran pengabdian ini adalah siswi MA Miftahul Ulum Kalirejo Pasuruan sebanyak 30 siswi yang dipilih secara acak untuk mengikuti pendampingan atau kegiatan pengabdian ini. Menurut Cresswell (2012) metode ini mendeskripsikan perencanaan serta mendeskripsikan hasilnya. Metode ini tidak menguji kevalidan hipotesis atau kerelevanan validasi hasil tetapi mendeskripsikan dan menganalisis data sehingga ditemukan bahan kajian lebih lanjut. Kegiatan Pengabdian Kepada Masyarakat ini terbagi menjadi 3 tahapan, yakni tahap persiapan, tahap pendampingan praktek dan tahap pemasaran, dengan rician sebagai berikut :

a. Tahap Persiapan

Pada tahap ini mahasiswa tim KKN STKIP-STIT PGRI Pasuruan didampingi dosen pembimbing lapangan melakukan observasi pada kegiatan ekstrakurikuler merajut. Observasi yang dilakukan adalah model take note, dimana para pengabdi mencatat hal-hal apa saja yang diperlukan untuk kegiatan pendampingan ini yang belum dimiliki oleh sasaran.Selanjutnya para pengabdi menyiapkan untuk memberikan workshop tentang pengetahuan dasar merajut.

b. Tahap Pendampingan dan Praktek

Tahap Pendampingan merupakan tahap pemberian pengetahuan dasar dan praktek awal merajut. Tahap ini dibagi lagi menjadi dua sesi yakni (1) sesi workshop, pada sesi ini para pengabdi memberikan workshop pengetahuan dasar merajut dan bagaimana tahapan merajut untuk pemula, (2) sesi pendampingan, sesi ini berlangsung selama satu minggu terhitung setelah workshop diselenggarakan sampai menghasilkan produk yang baik dan rapi yang siap untuk dipasarkan. Kuesioner selanjutnya diberikan setelah pendampingan untuk menganalisis perkembangan pengetahuan para siswi tentang teknik dan dasar merajut. Setelah kegiatan pendampingan atau workshop, terdapat kegiatan post workshop, yakni para siswi diharuskan untuk mengumpulkan hasil karya mereka atau produk hasil rajutan mereka dan dinilai oleh para pengabdi. Rajutan mereka dinilai dengan melihat sisi kerapian, kelayakan dan perpaduan warna (Crafts, 2019). Selanjutnya apabila rajutan tersebut sudah dinilai bagus dan terdapat lebih dari 15 siswi yang berhasil membuat produk rajutan yang bagus maka dapat masuk pada tahap pemasaran. Namun apabila hasil rajutan tersebut belum mencapai target rapi, layak dan belum baik perpaduan warnanya maka diadakan post workshop yang kedua atau tahap remedi. Yakni para siswi diberi waktu seminggu kembali untuk memperbaiki hasil rajutannya dan kemudian dinilai kembali oleh para pengabdi, sehingga apabila sudah mencapai lebih dari 15 hasil rajutan dinilai bagus, maka tahap pemasaran dapat dimulai.

c. Tahap Pemasaran

Tahap pemasaran merupakan tahap mulai memasarkan hasil rajutan melalui akun media sosial. Untuk pendampingan pertama ini, hasil rajutan perdana yang dihasilkan sisiwi MA Miftahul Ulum Kalirejo masih mendompleng pada akun pengabdi yakni akun instagram @rajutan_vani_pasuruan. Kemudian para pengabdi membuatkan akun lain yang khusus untuk pemasaran hasil rajutan sisiwi MA tersebut. Akun instagram untuk pemasaran yang 
akan dikelola para siswi adalah akun @madrasah_merajut. Akun tersebut akan beberapa hari didampingi dan dibantu pengelolaannya oleh para pengabdi, kemudian sepeninggal pengabdi, diharapkan akun tersebut sudah dapat dikelola sendiri oleh para siswi sehingga hasil penjualan dapat dikelola dari akun tersebut. Berikut adalah bagan tahapan pendampingan ekstrakurikuler merajut:

- Mengobservasi kegiatan merajut dan menemukan beberapa hal yang diperlukan siswa

- Menyiapkan hal-hal yang diperlukan

Persiapan
Pendampingan

dan Praktek

- Memberikan pengetahuan dasar merajut dan mengobservasi hasilnya

- praktek merajut dengan berbagai variasi model suvenir, bros, gantungan kunci, bungkus tempat pensil, dompet, bandana

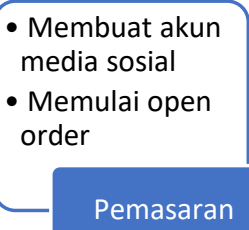

- Membuat akun media sosial

- Memulai open order

Pemasaran

Bagan 1. Tahapan pendampingan ekstrakurikuler merajut

Sasaran program pendampingan ini adalah 30 siswi MA Miftahul Ulum Kalirejo yang dipilih secara acak atau mendaftarkan dirinya sendiri untuk mengikuti pendampingan ini. Kegiatan pendampingan ini dilakukan selama 10 hari, meliputi satu hari workshop dan satu minggu praktek dan menghasilkan hasil rajutan dan tiga hari berikutnya adalah pemasaran.

\section{Hasil dan Pembahasan}

Kegiatan pendampingan ekstra kurikuler merajut ini dilakukan oleh mahasiswa tim KKN dengan didampingi oleh dosen pembimbing lapangan dengan sasaran 30 siswi peserta workshop merajut yang sebagian merupakan anggota kegiatan ekstrakurikuler merajut di MA Miftahul Ulum Kalirejo Pasuruan. Menurut Qomaruddin, et al., (2019) pada pengabdiannya di Desa Tumenggung, setiap desa dibagi menjadi beberapa kelompok kerja yang membuat hasil rajutan yang berbeda. Pada pengabdian ini, karena sasarannya adalah siswi MA sebanyak 30 orang maka kegiatan pendampingan dibagi menjadi dua tahap, yakni tahap workshop dan tahap praktek. Tahap workshop adalah tahapan untuk memperkenalkan pengatahuan dan teknik dasar merajut. Para siswi dibekali materi terkait merajut dan bagaimana cara merajut yang baik. Sepereti dikatakan sebelumnya pada pendahuluan, bahwa para siswi belum mempunyai pengetahuan tentang teknik dasar merajut, mereka hanya langsung praktek dengan kegiatan yang mereka sebut mbenthel. Salah satu aktivitas dari kegiatan workshop pengetahuan dasar merajut tersaji dalam gambar 1. 


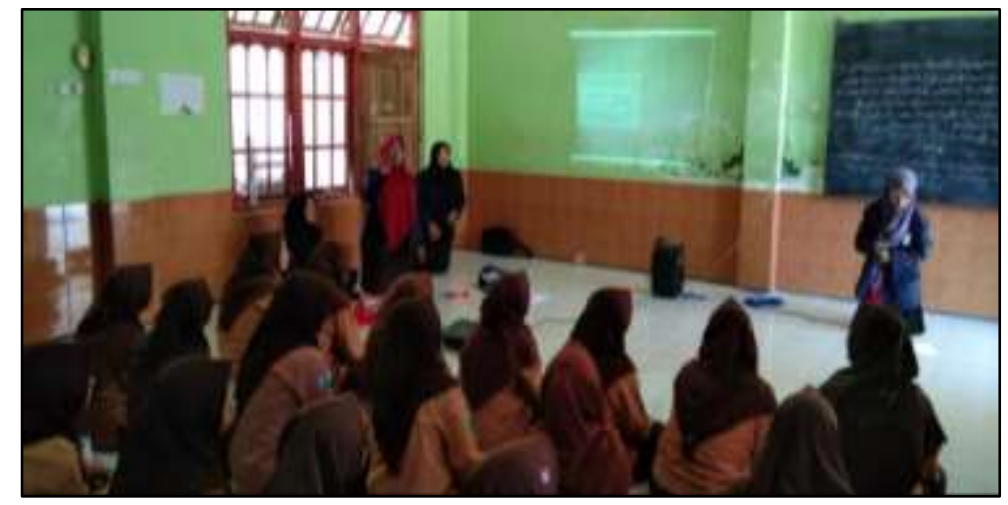

Gambar 1. Kegiatan Workshop Pengetahuan Dasar Merajut

Pada sesi workshop para siswa diberikan pengetahuan tentang teknik dasar merajut, seperti yang tertera pada gambar terdapat slide powerpoint yang ditunjukkan pada para siswi, slide powerpoint tersebut berisi materi tentang: (a) pengertian rajut, merajut dan merenda, (b) perbedaan merajut tradisional dan modern, (c) penjelasan dua teknik merajut, (d) pengenalan macam alat atau jarum untuk merajut, (d) teknik dasar memegang jarum saat merajut dan (e) macam teknik tusuk dalam merajut tipe crochet. Pada sesi workshop ini, terdapat sesi tanya jawab atau diskusi yang menambah pengetahuan para siswi tentang teknik dasar merajut, setelah workshop para siswi diberikan kuesioner untuk mengukur pengetahuan mereka setelah diberikan materi. Dari 30 siswi peserta pendampingan, 90\% dari mereka menjawab belum mengetahui teknik dan dasar merajut sebelum adanya workshop yang diselenggarakan oleh pengabdi. Sebanyak $75 \%$ mengatakan pernah merajut dan $90 \%$ menyatakan pengetahuan mereka bertambah dengan adanya workshop ini. Berikut adalah bagan peningkatan pengetahuan siswi terhadap teknik dan dasar merajut:

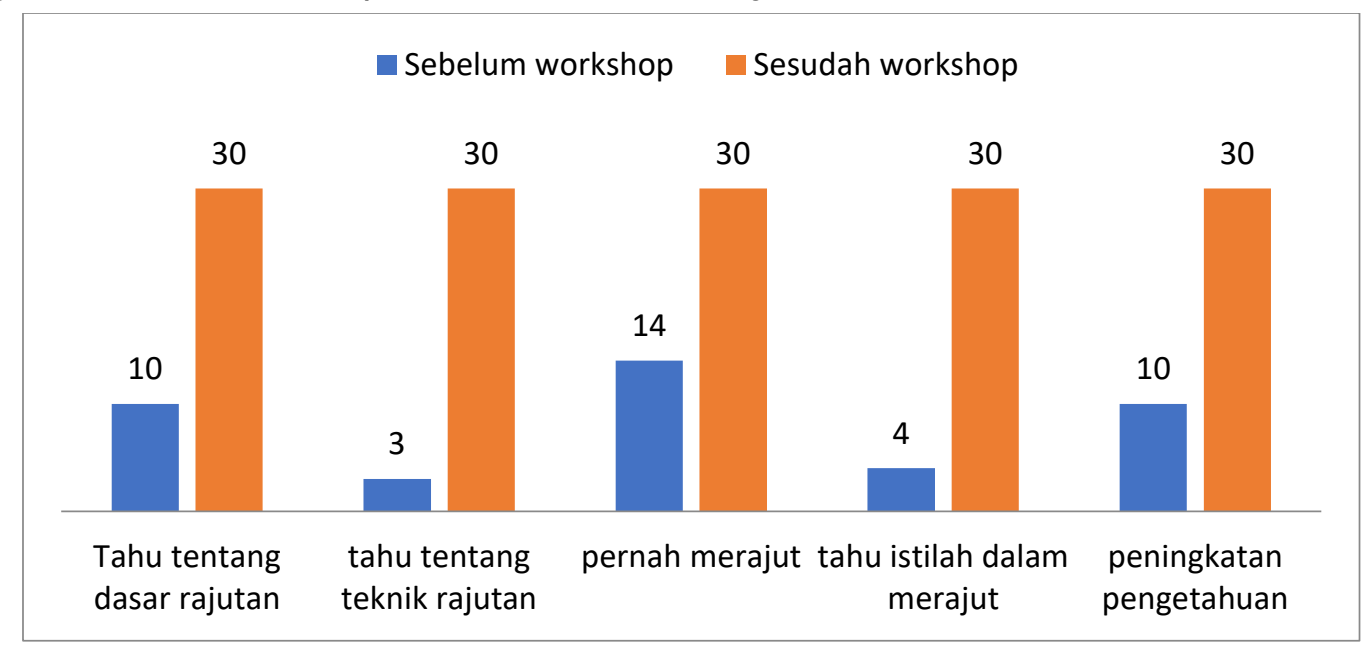

Bagan 2. Hasil peningkatan pengetahuan setelah adanya workshop

Setelah sesi workshop, sesi selanjutnya adalah praktek. Menurut Crafts (2019) terdapat dua macam jenis teknik merajut yakni knitting dan crochet, dalam pendampinga ini, para pengabdi kemudian memberikan contoh bagaimana merajut tipe crochet, yakni dengan menggunakan satu jarum yang bernama hakpen dan benang, teknisnya jarus ditusukkan ke atas dab ke bawah sehingga membentuk pola seperti huruf $\mathrm{V}$ yang beraturan. 
Para siswi target pengabdian, mendapatkan masing-masing satu bundel benang rajut dan satu jarum. Mereka kemudian dituntun dan didampingi bagaimana merajut dengan teknik crochetyang baik. Hasil dari rajutan teknik crochetberbeda dengan teknik knitting. Untuk teknik crochet yang dipilih dalam pendampingan ini, hasil rajutannya agak kaku, dan cocok untuk memproduksi suvenir seperti gantungan kunci, bandana, dompet, tempat pensil dan bros. Sehingga pada pendampingan ini, diharapkan siswi dapat menjual hasil rajutan mereka.
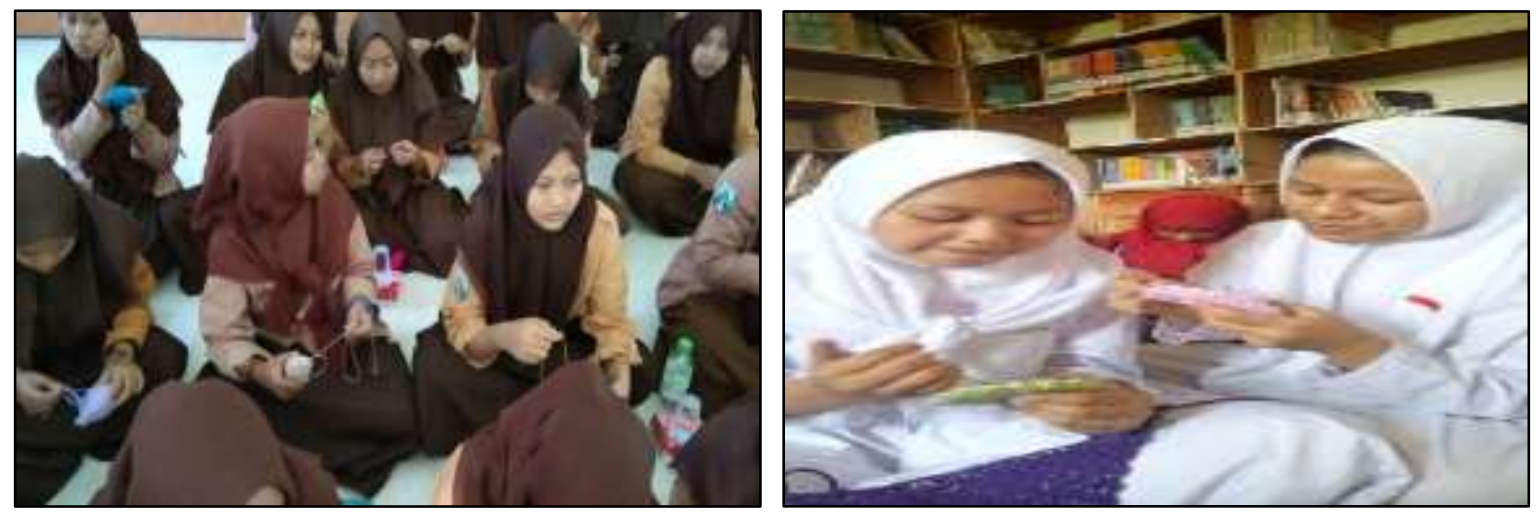

Gambar 2. Kegiatan merajut para siswi

Kegiatan selanjutnya yang dilaksanakan pada tahap pendampingan adalah praktek. Dalam praktek ini para pengabdi membagi para sisiwi menjadi beberapa kelompok kecil sehingga dapat mendampingi dengan efektif, hal ini sejalan dengan apa yang dilakukan oleh Qomaruddin et al., (2019) pada pengabdiannya di Desa Tumenggung, setiap desa dibagi menjadi bebrapa kelompok kerja yang membuat hasil rajutan yang berbeda. Dalam waktu satu jam, para pengabdi memberikan contoh teknik tusuk dalam merajut tipe crochet. Kegiatan pendampingan ini terlaksana dengan sangat intens karena, para siswi peserta pendampingan tidak merasa sungkan untuk bertanya pada para pengabdi, sehingga suasana menjadi cair dan menyenangkan.

Praktek kemudian dilanjutkan dalam waktu seminggu setelah workshop, setiap hari pada jam istirahat para siswi menemui para pengabdi untuk melanjutkan pendampingan merajut, mereka memperoleh saran-saran dalam meneruskan membuat produk rajutnya. Kemudian setelah satu minggu masing-masing siswi menyetorkan hasil rajutannya untuk kemudian diobservasi, dinilai dan dipilih mana yang belum rapi dan mana yang sudah rapi. Penilaian hasil rajutan diambil dari Crafts (2019) yakni dinilai aspek kerapian, kelayakan dan keindahan perpaduan warna. Hasil rajutan dapat dilanjutkan pada tahap pemasaran jika terdapat 15 hasil atau lebih masuk pada kriteria rapi, layak, dan baik. Untuk hasil yang belum memenuhi target, maka para pengabdi masih melanjutkan pendampingan hingga hasil benar-benar rapi dan layak jual. Pendampingan lanjut ini disebut remedi. Pendampingan remedi dilakukan setelah para siswi menyetorkan hasil perdana mereka post-workshop atau setelah workshop. Pendampingan remedi juga dilakukan dalam seminggu, hingga dicapai hasil rajutan yang layak jual. Pada post workshop pertama, setelah dilakukan penilaian, hasilnya masih banyak hasil rajutan yang belum memenuhi kriteria yakni hanya terdapat 10 hasil rajutan yang dinilai rapi, layak dan baik. Sedangkan 20 sisanya masih perlu proses pendampingan lagi. Sehingga tahap pemasaran 
ditunda seminggu demi mendapatkan hasil yang memenuhi kriteria penilaian. Setelah waktu pendampingan diberikan, maka para pengabdi kembali mengumpulkan hasil rajutan dan menilainya. Hasilnya terdapat 18 siswi yang mengahsilkan rajutan rapi dan baik perpaduan warnanya, serta 20 siswi memiliki hasil rajutan yang layak jual, hal ini dapat disimpulkan bahwa tahap pemasaran dapat dilakukan karena terdapat peningkatan setelah kegiatan pendampinga post workshop kedua. Berikut adalah beberapa hasil dan bagan peningkatan hasil rajutan:

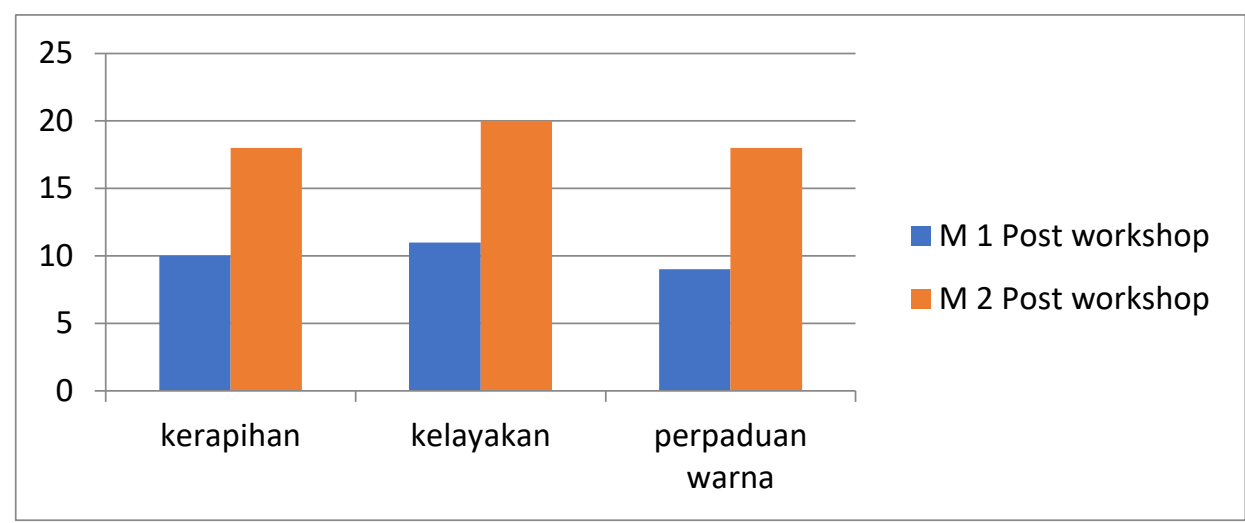

Bagan 3. Peningkatan hasil rajutan

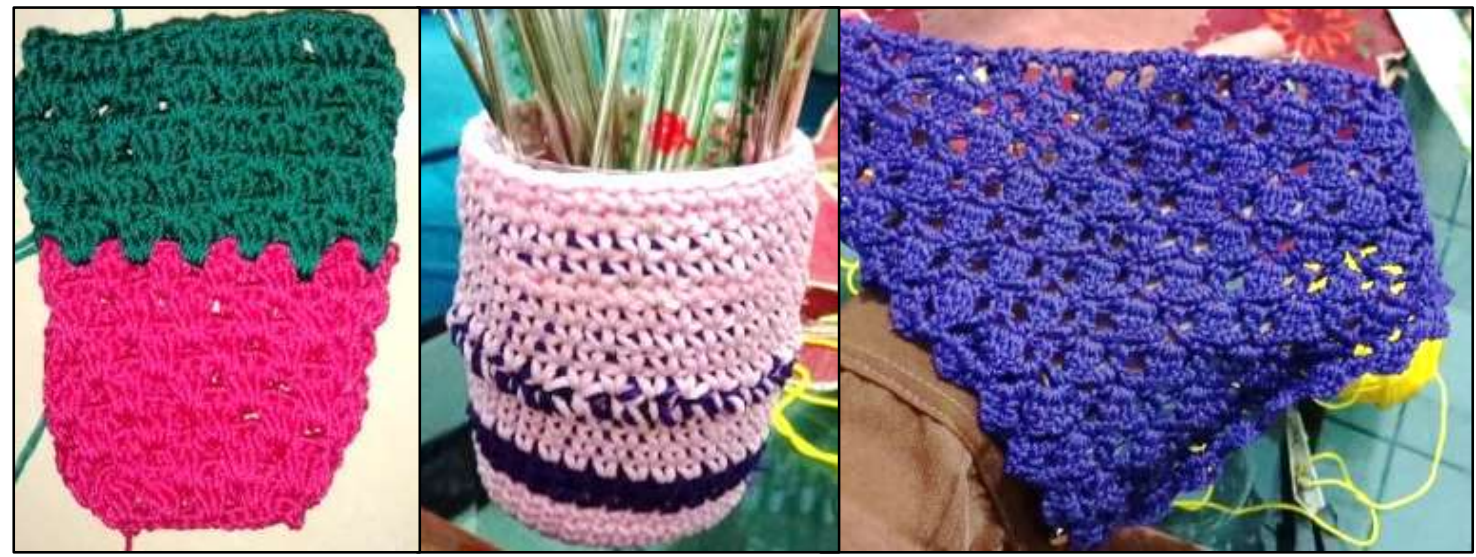

Gambar 3. Beberapa hasil rajutan (dompet, bungkus tempat pensil dan bandana)

Dilihat dari bagan dan hasil rajutan di atas, kegiatan pendampingan ini dapat dikatakan berhasil. Keberhasilannya dapat diurkur dari : (a) meningkatnya pengetahuan para siswi peserta ekstrakurikuler tentang teknis dan dasar merajut, (b) meningkatnya variasi hasil rajutan dan (c) meningkatnya kerapian hasil rajutan. Setelah pendampingan selesai, tahap berikutnya dalam kegiatan pengabdian ini adalah pemasaran.

Tahap pemasaran terlebih dulu dikelola oleh mahasiswa KKN (pengabdi) yang melibatkan tiga orang siswi terpilih. Sebanyak tiga orang siswi ini kemudian diajari cara membuka akun media sosial, dalam hal ini instagram dan bagaimana berinteraksi dengan para netizen. Untuk minggu pertama tahap pemasaran, akun yang digunakan adalah akun @rajutan_vani_pasuruan yakni akun milik salah satu pengabdi. Tiga orang siswi yang terpilih tadi diberi akses pada akun tersebut sembari mempersiapkan akun mereka sendiri. Setelah diajari dan didampingi cara mengelola akunmedia sosial, mereka dibukakan akun baru bernama @madrasah_merajut dengan 3 siswi tersebut sebagai 
pengelolanya. Hal ini sejalan dengan Salwendri dan Siregar (2018) yang memanfaatkan media sosial sebagai peluang usaha kelompok karang taruna. Dalam Salwendri dan Siregar (2018) dinyatakan bahwa media sosial bukan hanya media hiburan tetapi juga dapat membangkitkan kesiapan berwirausaha. Hal inilah yang dilakukan tim pengabdi pada siswi sasaran, sehingga mereka tidak hanya bermain di media sosial tetapi juga berwirausaha.

Pendampingan pemasaran dilakukan setelah tahap workshop dan pendampingan remedi tadi, yakni dimulai pada 23 November sampai dengan 1 Desember 2019. Selanjutnya para siswi meengelola sendiri akun mereka, menerima pre-order, mengirimkan barang dan mengelola keuangan. Tentu hal ini juga didampingi oleh Wakil Kepala Madrasah Bidang Kesiswaan. Sampai artikel ini ditulis, terdapat beberapa order atau pesanan, yang paling banyak adalah pesanan hiasan tempat pensil seperti dalam gambar 4 sisi tengah.

\section{Kesimpulan}

Peningkatan-peningkatan terlihat pada kegiatan ekstrakurikuler ini yaitu: (a) meningkatnya pengetahuan para siswi peserta workshop tentang teknik dasar merajut, (b) meningkatnya pengetahuan para siswi peserta pendampingan akan perbedaan teknik merajut yang biasa dipakai di Indonesia, (c) meningkatnya pengetahuan tentang macam-macam jenis merajut, (d) meningkatnya keterampilan siswi peserta pendampingan dalam berkreasi membuat hasil rajutan yang bervariasi , (e) meningkatnya kemampuan para siswi peserta pendampingan dalam mebuat hasil rajutan yang rapi, padu padan warna yang indah dan layak jual., (f) meningkatnya pengetahuan siswi peserta pendampingan akan pemasaran yang tidak hanya melalui pasar offline tetapi juga dapat melalui pasar online dan ( $\mathrm{g}$ ) terdapatnya akun media sosial bagi para siswi untuk memasarkan hasil rajutannya yakni akun instagram @madrasah_merajut.

Kegiatan ini juga telah meningkatkan pemikiran para siswi yang dulunya mengikuti kegiatan ekstrakurikuler sebagai suatu kegiatan wajib namu sekarang mereka dengan senang hati dan antusias mengikuti kegiatan ekstrakurikuler dengan adanya peningkatan-peningkatan perilaku dan keterampilan yang disebutkan di atas. Harapan selanjutnya, sepeninggal tim pengabdi (mahasiswa KKN) akun media sosial yang menjadi wadah pemasaran tersebut dapat senantiasa berguna dan digunakan oleh para siswi yang didampingi oleh Wakil Kepala Madrasah agar terus menggenjot permintaan pasar dan menghasilkan pundi-pundi keuangan yang dapat digunakan untuk keberlangsungan kegiatan ektrakurikuler merajut ini.

\section{Ucapan Terima Kasih}

Kegiatan pengabdian pada masyarakat ini merupakan kegiatan tim KKN STKIP-STIT PGRI Pasuruan yang berempat di MA Miftahul Ulum Kalirejo Pasuruan. Oleh karenanya para penulis yang juga sebagai para pengabdi mengucapkan terima kasih yang tak terhingga kepada Kepala MA Miftahul Ulum Kalirejo dan Wakil Kepala Sekolah yang dengan senang hati bekerja sama atas terselenggaranya program pendampingan ini, juga terima kasih atas kerja keras tim KKN yang selama kurang lebih satu bulan melakukan pendampingan. 


\section{Referensi}

Budi, A., Mhd, P., \& Niza, A. (2018). IbM pengembangan rajutan di kampung Aur Medan. Logista, $2(1), 21-30$.

Crafts, M. (2019). Mengenal Jarum Rajut-Knitting and Crocheting. Retrieved November 20, 2019, from Maya Crafts website: https://www.mayacrafts.asia/mengenal-jarum-rajut/

Cresswell, J. (2012). Educational Research Planning, Conducting, and Evaluating Quantitative and Qualitative Research (Vol. 1). United States: Pearson Education.

Habibullah, J., Roslina, Rinaldi, B., \& Zainnur, M. R. (2018). Pemberdayaan Perempuan Dalam Rang Meningkatkan Ekonomi Keluarga: Pengenalan Usaha Rajutan di Kelurahan Enggal, Kecamatan Enggal, Kota Bandar Lampung. Prosiding Seminar Nasional Pengabdian Kepada Masyarakat "Pengabdian Kepada Masyarakat Melalui Diseminasi Hasil Penelitian Terapan,"121-126.

Halimah, N. (2014). Pelaksanaan Pengembangan Diri di SMP Negeri 23 Padang (Sekolah Penyelenggara Pendidikan Inklusif). Jurnal Ilmiah Pendidikan Khusus, 3(3), 41-52.

Kartika, N. (2014). Pengembangan Modul Pembelajaran Pembuatan Rajutan dan Kaitan Pada Mata Pelajaran Tekstil Siswa Kelas X Busana Butik di SMK Negeri 3 Klaten. Universitas Negeri Yogyakarta.

Masiah, M., \& Adawiyah, S.R. (2018). Pemberdayaan Remaja Melalui Keterampilan Produk Handmade Sebagai Upaya Mencegah Pernikahan Dini. Transformasi: Jurnal Pengabdian Masyarakat, 14(2), 131-138. https://doi.org/10.20414/transformasi.v14i2.586

Qomaruddin, N., Munawaroh, E., Adib, R.B., Nurul, M. N. (2019). Efektivitas Pelatihan Keterampilan Merajut dalam Menambahkan Daya Kreativitas Warga Dusun Temanggung Kelurahan Jetis Kecamatan Saptosari Kabupaten Gunungkidul DIY. Prosiding Konferensi Pengabdian Masyarakat, 1, 129-131.

Salwendri, \& Siregar, O. M. (2018). Pemanfaatan Media Sosial Sebagai Peluang Usaha Kelompok Pemuda Karang Taruna di Kelurahan Pulo Brayan Bengkel Medan. Abdimas Talenta, 3(2), 379383.

Siswanto, B., Mochtar, D. A., \& Prihantono, E. Y. (2016). Ketrampilan Rajut Mengantar Siswa SMK El Hayat Siap Berwirausaha. Jurnal Abdimas Unmer Malang, 1(1), 7-11.

Srikandi, Aisyah, S., \& Rosmiaty. (2018). PKM Pengenalan Wirausaha Melalui Keterampilan Merajut Pada Anak Panti Asuhan Sejati Muhammadiyah Kota Makassar. Prosiding Seminar Nasional Universitas Negeri Makassar, 11-13.

Widyastuti, E., \& Sari, I. P. (2017). Pelatihan Dan Pendampingan Keterampilan Merajut Dan Manajemen Usaha Di Desa Telaga Sari - Deli Serdang. Seminar Nasional Pengabdian Masyarakat Lpm Unimed 2017, 177-183. 